Wulida Nurul Fauziah, dkk. Penggunaan Metode Pembelajaran... Halaman $230-243$

Jurnal Belajar Bahasa, ISSN 2502-5864, E-ISSN 2503-0329

Volume 3, No. 2, September 2018

\title{
PENGGUNAAN METODE PEMBELAJARAN \\ BAHASA INDONESIA BAGI PENUTUR ASING
}

\author{
Wulida Nurul Fauziah \\ Deden Ahmad Supendi \\ Hera Wahdah Humaira \\ Universitas Muhammadiyah Sukabumi \\ dedenahmadsupendi118@ummi.ac.id
}

\begin{abstract}
ABSTRAK
Penelitian ini dilatarbelakangi oleh meningkatnya eksistensi bahasa Indonesia di kancah dunia, oleh karena itu saat ini banyak lembaga formal baik di luar negeri maupun di Indonesia yang memfasilitasi masyarakat dari berbagai negara untuk mempelajari bahasa Indonesia. Dalampembelajaranbahasa Indonesia bagi pembelajar asing tidaklah mudah sehingga diperlukannya strategi atau metode yang sesuai. Kurangnya informasi mengenai penggunaan metode pembelajaran bahasa Indonesia bagi pembelajar asing menjadi alasan peneliti untuk melakukan penelitian penggunaan metode pembelajaran bahasa Indonesia bagi penutur asing di salah satu lembaga formal luar negeri yaitu Nirandonwitya School Thailand bagian selatan. Metode penelitian yang digunakan adalah deskriptif kualitatif. Peneliti hadir sebagai pengamat sekaligus berpartisipasi terlibat aktif dalam proses pembelajaran bahasa Indonesia siswa Mathayom Nirandonwitya School untuk menganalisis penggunaan metode dalam pembelajaran bahasa Indonesia bagi penutur asing. Berdasarkan hasil penelitian ditemukan delapan metode dalam pembelajaran bahasa Indonesia yang digunakan di berbagai kelas dengan materi yang berbeda. Kedelapan metode tersebut yaitu metode baca tirukan, mambaca berantai, demonstrasi, ceramah, deskripsi gambar, menyanyikan lagu, scramble dan teka-teki silang. Kedelapan metode tersebut digunakan untuk meningkatkan keterampilan berbahasa pembelajar yaitu keterampilan menyimak, berbicara, membaca dan menulis. Analisis kesesuaian penggunaan metode yang digunakan guru dilakukan dengan mengacuke pada teori yang ada, sehingga ditemukan kelebihan dan kelemahan dalam setiap metode.
\end{abstract}

Kata Kunci: BIPA, metode, Nirandonwitya, pembelajaran

\begin{abstract}
This research is urgedby the increasing existence of Indonesian language in the world arena. Hence, a lot of formal institutions both abroad and in Indonesia facilitate the community from various countries to learn the Indonesian language nowadays. Learning Indonesian for foreign learners is not easy, therefore precise strategy or method is required. Lack of information about the use of Indonesian learning methods for foreign learners is the reason researchers to conduct research on the use of Indonesian language learning methods for foreign learners in one of the formal institutions abroad namely Nirandonwitya School of southern Thailand. The research method used is descriptive qualitative. The researcher acted as both an observer and participant observer who actively involved in the Indonesian language learning process of the students Mathayom Nirandonwitya School to analyze the use of methods in Indonesian language learning for foreign speakers. The results of research found eight methods in learning Indonesian language used in different classes with different materials. The eight methods are read and repeat, chain reading, demonstration, lecture, picture description, singing song, scramble and crossword puzzle. The eight
\end{abstract}


Wulida Nurul Fauziah, dkk. Penggunaan Metode Pembelajaran... Halaman $230-243$ Jurnal Belajar Bahasa, ISSN 2502-5864, E-ISSN 2503-0329

Volume 3, No. 2, September 2018

methods are used to improve the language skills of learners in listening, speaking, reading and writing. Analysis of the suitability of the methods used by referring to the existing theory, so that the advantages and weaknesses in each method are found.

Keywords: BIPA, learning, method, Nirandonwitya

\section{PENDAHULUAN}

Pendahuluan mencakup urgensi isu/ permasalahan dan rasionalisasi Bahasa Indonesia merupakan bahasa nasional dan bahasa negara Indonesia yang pada mulanya memiliki cikal bakal dari bahasa Melayu sampai pada akhirnya bahasa Indonesia diresmikan menjadi bahasa nasional pada tahun 1945. Indonesia merupakan negara yang memiliki kekuatan atau sangat berpengaruh baik dari segi ekonomi maupun budaya di ASEAN, sehingga menyebabkan eksistensi bahasa Indonesia semakin tinggi dan memungkinkan bahasa Indonesia menjadi bahasa pengantar dalam Masyarakat Ekonomi Asean selain bahasa Inggris (Ngelu, 2015). Hal tersebut dibuktikan dengan semakin banyaknya penutur asing yang memiliki minat untuk mempelajari bahasa Indonesia dengan adanya lembaga-lembaga formal di luar negeri yang memfasilitasi pembelajaran bahasa Indonesia, sebagaimana yang dikemukakan Wahyasebanyak 219 lembaga formal di 74 negara telah menyelenggarakan pembelajaran bahasa Indonesia (Kusmiatun, 2016, hal. 3). Selain itu di Indonesia sendiri terdapat program Darmasiswa. Darmasiswa adalah program yang bertujuan untuk mempromosikan dan meningkatkan minat terhadap bahasa dan budaya Indonesia di kalangan pemuda dari negara lain (Muliastuti, 2017, hal. 2). Dari situs darmasiswa.kemendiknas.go.id di- peroleh data bahwa minat mahasiswa asing yang mengikuti program tersebut semakin meningkat (Muliastuti, 2017, hal. 2-3). Jumlah alumni pada tahu 2008 mencapai angka 2.037 dari 85 negara. Hingga tahun 2013 total mahasiswa asing yang mengikuti program tersebut berjumlah 4.563 orang yang berasal dari 97 negara.

Dalam suatu pemerolehan bahasa dikenal dengan nama bahasa ibu dan bahasa kedua atau bahasa asing. Bahasa ibu merupakan bahasa pertama yang diperoleh seseorang dari lahir yang berasal dari keluarganya, sedangkan bahasa kedua merupakan bahasa yang diperoleh seseorang setelah bahasa ibu, bahasa kedua ini bisa saja bahasa daerah yang juga dipakai dalam berkomunikasi sehari-hari atau bahasa lainnya yang dikuasai atau dipelajari oleh seseorang. Ellis mengemukakan bahwa antara bahasa kedua dengan bahasa asing keduanya dapat dicermati sebagai dua hal yang berbeda (Kusmiatun, 2016, hal. 18). Bahasa kedua memang bukan bahasa utama, tetapi bahasa tersebut merupakan bahasa umum di sebagai alat komunikasi umum pada suatu wilayah atau negara tempat bahasa tersebut diajarkan.

Dengan demikian berdasarkan pernyataan tersebut bahasa kedua merupakan alat komunikasi alternatif yang dipakai sehari-hari oleh penuturnya. Sedangkan bahasa asing merupakan bahasa yang 
Wulida Nurul Fauziah, dkk. Penggunaan Metode Pembelajaran... Halaman $230-243$ Jurnal Belajar Bahasa, ISSN 2502-5864, E-ISSN 2503-0329

Volume 3, No. 2, September 2018

dengan sengaja dipelajari oleh seseorang dengan tujuan tertentu dan akan digunakan pada waktu atau situasi tertentu pula.

Thailand merupakan salah satu negara yang mempelajari bahasa Indonesia sebagai bahasa asing di negaranya. Thailand bagian selatan merupakan negara yang mayoritas menggunakan bahasa Thailand sebagai bahasa ibu, kemudian bahasa melayu sebagai bahasa kedua. Sedangkan bahasa Indonesia memiliki kedudukan yang sama seperti halnya bahasa Inggris yaitu sebagai bahasa asing yang mereka peroleh dan pelajari baik secara formal maupun informal.

Nirandonwitya School merupakan salah satu lembaga formal yang berada di Thailand bagian Selatan, di mana sistem pendidikan atau kurikulum yang dimilikinya terdapat mata pelajaran bahasa asing termasuk mata pelajaran Indonesia sebagai pilihan mata pelajaran asing.

Suatu proses pembelajaran bahasa Indonesia yang dilakukan bagi pembelajar bahasa Indonesia yang belum menguasai bahasa tersebut atau dapat dikatakan penutur asing tidaklah mudah dalam menyampaikannya, dengan demikian diperlukannya strategi atau metode pembelajaran yang sesuai sehingga dapat mempermudah kegiatan pembelajaran bahasa Indonesia yang dilakukan.

Metode adalah suatu cara yang digunakan untuk mencapai suatu tujuan tertentu yang telah ditetapkan. Begitu pula dalam kegiatan belajar mengajar, metode sangat diperlukan oleh seorang guru dalam proses pembelajaram, agar tujuan pembelajaran dapat tercapai sebagai mana mestinya.

Menurut Djamarah, dkk. metode memiliki kedudukan sebagai alat motivasi ekstrinsik dalam kegiatan belajar mengajar, dapat menyiasati perbedaan individual anak didik serta untuk mencapai tujuan pembelajaran (Faturrohman \& Sutikno, 2010, hal. 55).

Dalam melaksanakan proses pembelajaran suatu materi pembelajaran perlu dipikirkan metode pembelajaran yang tepat. Ketepatan (efektivitas) penggunaan metode pembelajran tergantung pada kesesuaian metode pembelajaran dengan beberapa faktor, yaitu tujuan pembelajaran, materi pembelajaran, kemampuan guru, kondisi siswa, sumber atau fasilitas, situasi kondisi dan waktu (Sumiati \& Asra, 2009, hal. 92).

Berdasarkan hal tersebut dengan sebuah metode atau teknik mengajar yang baik dan sesuai dapat membantu siswa dalam memahami pembelajaran, terlebih lagi jika seorang pengajar tidak terlalu menguasai bahasa ibu mereka, oleh karena itu penguasaan teknik atau metode pembelajaran yang beragam sangat diperlukan agar proses pembelajaran bahasa Indonesia dapat berjalan dengan efektif. Dengan demikian pada kesempatan kali ini penulis tertarik untuk mengetahui metode apa saja yang dapat digunakan dalam sebuah pembelajaran pemerolehan bahasa Indonesia bagi pembelajar atau penutur asing yang akandilakukan di sekolah tingkat Mathayom Nirandonwitya School 
Wulida Nurul Fauziah, dkk. Penggunaan Metode Pembelajaran... Halaman $230-243$ Jurnal Belajar Bahasa, ISSN 2502-5864, E-ISSN 2503-0329

Volume 3, No. 2, September 2018

tahun 2017-2018. Maka, untuk mengetahui hal tersebut penulis bermaksud untuk meneliti atau menganalisis penggunaan metode pembelajaran bahasa Indonesia siswa di tingkat Mathayom Nirandonwitya School, Narathiwat, Thailand Selatan.

Jika seorang pembelajar asing belajar bahasa Indonesia di Indonesia, maka situasi pembelajarannya menjadi sitruasi pembelajaran B2 atau bahasa kedua. Namun, jika pembelajaran bahasa Indonesia dilakukan di negara mereka, maka situasi pembelajarannya menjadi situasi pembelalajaran bahasa asing (Muliastuti, 2017, hal. 14).

Kurangnya informasi tentang penelitian pembelajaran bahasa Indonesia bagi pembelajar asing khususnya mengenai penggunaan metode pembelajaran yang efektif sehingga pengajar masih kesulitan dalam melakukan pengajaran bahasa Indonesia bagi pembelajar asing. Melalui penelitian yang akan dilakukan diharapkan dapat menjadi informasi dan menjadi bahan pertimbangan bagi pengajar bahasa Indonesia dalam menggunakan metode pembelajaran bahasa Indonesia bagi pembelajar asing. Karena seperti yang kita ketahui bahwa karakteristik pembelajar asing dalam pembelajaran bahasa Indonesia sebagai bahasa asing bagi seorang pengajar tentu berbeda dengan pembelajar yang dimana bahasa Indonesia sebagai bahasa ibu mereka. Dengan demikian melalui penggunaan metode yang efektif sasaran akhir pengajaran bahasa Indonesia bagi pembelajar asing adalah terampil

menggunakan bahasa Indonesia dengan baik dan benar. Keterampilan tersebut meliputi empat keterampilan berbahasa, yaitu membaca, menulis, menyimak dan berbicara.

Pengajaran bahasa asing merupakan salah satu ilmu yang popular dipelajari di seluruh dunia. Para ahli bahasa berpendapat bahwa dengan mempelajari bahasa suatu negara sebagai bahasa asing berarti mempelajari kebudayaan masyarakat bahasa negara tersebut. Selain itu, dengan menguasai lebih dari satu bahasa akan membantu mereka dalam persaingan dunia kerja di era globalisasi seperti sekarang (Iskandarwassid, 2008, hal. 274).

Adapun tujuan seseorang belajar bahasa asing adalah sebagai berikut.

a. Tujuan integratif, yaitu pembelajar ingin berkomunikasi dengan orang di seluruh dunia atau dalam negeri sendiri yang berbicara bahasa target, atau untuk bertahan hidup di budaya lain dengan bahasa target adalah bahasa utama yang digunakan.

b. Tujuan instrumental, yaitu pembelajar ingin melakukan perjalanan, atau bekerja di negara lain dengan bahasa target adalah abahasa utama yang digunakan, selain itu untuk mempelajari bidang tertentu atau mendapatkan pekerjaan dalam lingkungan lokal mereka sendiri yang mengahruskan mereka bilingual, atau sebagai sarana untuk memenuhi persyaratan kelulusan untuk melanjutkan studi ke tingkat yang lebih tinggi. 
Wulida Nurul Fauziah, dkk. Penggunaan Metode Pembelajaran... Halaman $230-243$ Jurnal Belajar Bahasa, ISSN 2502-5864, E-ISSN 2503-0329

Volume 3, No. 2, September 2018

c. Tujuan personal, yaitu jika pembelajar merasa bahwa belajar bahasa lain adalah pengetahuan yang menguntungkan dan memperkaya wawasannya karena memberikan perspektif baru yang menarik (Muliastuti, 2017, hal. 15-16).

Metode pembelajaran merupakan bagian dari strategi intruksional, metode intruksional berfungsi sebagai cara guru untuk melakukan atau menyajikan, menguraikan, memberi contoh, dan memberi latihan isi pelajaran kepada peserta didik untuk mencapai tujuan tertentu (Yamin, 2013, hal. 8). Metode adalah cara guru menjelaskan konsep, fakta dan prinsip kepada peserta didik dengan cara pendekatan pembelajaran berpusat pada guru (teacher oriented) dan pembelajaran berpusat pada peserta didik (studentoriented).

Tarigan juga mengemukakan pengertian yang selaras mengenai metode yang menyatakan bahwa metode merupakan rencana keseluruhan bagi bahan pembelajaran secara rapi dan tertib, tidak ada bagian yang berkontradiksi dan semua itu didasarkan pada pendekatan yang terpilih (Tarigan, 2009, hal. 10).

Berdasarkan beberapa pendapat yang telah dikemukakan di atas, maka dapat dikatakan bahwa metode adalah bagian dari suatu strategi yang merupakan cara atau teknik yang digunakan untuk mencapai suatu tujuan tertentu yang telah ditetapkan. Begitu pula dalam kegiatan belajar mengajar, metode pembelajaran merupakan suatu cara yang digunakan oleh seorang guru dalam

proses pembelajaran yang efektif. Dengan demikian, menentukan metode pembelajaran merupakan langkah penting dalam proses pembelajaran yang dapat menunjang keefektifan proses pembelajaran serta keberhasilan pencapaian tujuan. Metode pembelajaran harus disesuaikan pula dengan materi dan tujuan pembelajaran, juga ditetapkan dengan melihat kegiatan pembelajaran yang akan dilakukan.

Ketika menggunkan metode dalam situasi kegiatan belajar mengajar seperti yang dikemukakan Sumiati dan Asra (Sumiati \& Asra, 2009, hal. 92-96), terdapat aspek-aspek yang perlu diperhatikan diantaranya yaitu adanya kesesuaian metode pembelajaran dengan tujuan pembelajaran, kesesuaian metode pembelajaran dengan materi pembelajaran, kesesuaian metode pembelajaran dengan kemampuan guru, kesesuaian metode pembelajaran dengan kondisi siswa, kesesuaian metode pembelajaran dengan sumber dan fasilitas yang tersedia, dan kesesuaian metode pembelajaran dengan waktu yang tersedia.

Setiap metode pembelajaran mempunyai keunggulan dan kelemahan dibandingkan dengan yang lain. Tidak ada satu metodepun yang dianggap selalu efektif untuk segalasituasi pembelajaran. Berikut ini merupakan berbagai metode pembelajaran yang memungkinkan dapat diterapkan di dalam kelas, yaitu sebagai berikut.

a. Metode ceramah (lecture)

Langkah-langkah yang terdapat dalam metode ceramah pada 
Wulida Nurul Fauziah, dkk. Penggunaan Metode Pembelajaran... Halaman $230-243$ Jurnal Belajar Bahasa, ISSN 2502-5864, E-ISSN 2503-0329

Volume 3, No. 2, September 2018

pembelajaran bahasa Indonesia yaitu sebagai berikut (Roestiyah, 2001, hal. 137).

1) Langkah persiapan. Persiapan yang dimaksud di sini adalah menjelaskan kepada siswa tentang tujuan pembelajaran dan pokokpokok masalah yang akan dibahas yang akan dibahas dalam pelajaran tersebut.

2) Langkah penyajian. Pada tahap ini guru menyajikan bahan yang berkenaan dengan pokok-pokok masalah.

3) Langkah generalisasi. Pada tahap ini unsur yang sama atau berlainan selama proses pembelajaran akan dihimpun untuk mendapatkan kesimpulankesimpulan mengenai pokokpokok masalah.

4) Langkah aplikasi penggunaan. Pada tahap ini kesimpulan yang telah diperoleh diharapkan dapat digunakan dalam berbagai situasi sehingga hasil kesimpulan yang diperoleh terlihat nyata.

b. Metode Demonstrasi

Adapun langkah-langkah yang terdapat dalam penggunaan metode deminstrasi seperti yang dikemukakan oleh Hasibuan dan Mujiono (Darmadi, 2017 , hal. 189) yang dilengkapi oleh Saifuddin (Saifuddin, 2014, hal. 145146) adalah sebagai berikut.

1) Merumuskan dengan jelas kecakapan dan atau keterampilan apa yang diharapkan dicapai oleh siswa sesudah demonstrasi itu dilakukan.
2) Mempertimbangkan dengan sungguh-sungguh, apakah metode itu wajar digunakan serta efektif untuk mencapai tujuan pembelajaran yang dirumuskan.

3) Alat-alat yang diperlukan untuk demonstrasi itu bisa didapat dengan mudah dan sudah dicoba terlebih dahulu.

4) Guru menyampaikan gambaran sekilas mengenai materi pembelajaran.

5) Siswa mendemonstrasikan sesuai dengan skenario pembelajaran yang telah disiapkan.

6) Setiap siswa memperhatikan demonstrasi dan menganalisisnya.

7) Setiap siswa mengemukakan hasil analisisnya dan juga pengalaman siswa didemonstrasikan.

8) Guru bersama siswa membuat simpulan.

c. Metode deskripsi gambar

Langkah-langkah yang terdapat dalam metode deskripsi gambar pada pembelajaran bahasa Indonesia yaitu sebagai berikut.

1) Sediakan gambar (foto) dari koran atau majalah.

2) Simpan gambar tersebut di meja guru atau papan tulis.

3) Guru mendeskripsikan salah satu gambar yang ada di papan tulis atau meja.

4) Selesai guru mendeskripsikan gambar secara rinci, guru meminta siswa untuk mendeskripsikan gambar lain dengan mengamati dengan detail ciri-ciri yang terdapat dalam 
Wulida Nurul Fauziah, dkk. Penggunaan Metode Pembelajaran... Halaman $230-243$ Jurnal Belajar Bahasa, ISSN 2502-5864, E-ISSN 2503-0329

Volume 3, No. 2, September 2018

gambar tersebut. (Maulana, 2015, hal. 90)

d. Metode menyanyikan lagu

Penggunaan metode menyanyi, musik dan parodi adalah bentuk kreativitas pengajaran yang membantu siswa dalam mengingat pelajaran (Said \& Rahayu, 2017, hal. 35-36). Adapun langkah-langkah yang digunakan dalam penggunaan metode menyanyikan lagu adalah sebagai berikut.

1) Mengubah lirik pembelajaran. Lirik yang digunakan dalam pembelajaran sebiaknya mudah diingat, enak dinyanyikan dan memiliki makna serta dekat dengan keseharian pembelajar.

2) Mengaransemen materi pembelajaran. Setelah menemukan lirik yang berkaitan dengan pembelajaran, selanjutnya lirik tersebut diaransemen dan dipadukan dengan musik yang harmonis.

3) Mengolah nada pembelajaran. Dalam pembelajaran di kelas tujuh nada yang biasa dimainkan musisi dapat dilambangakan dengan tujuh unsur aktivitas yang biasa dilakukan oleh sis wa dalam proses pembelajaran, yaitu Coba, Dengar, Evaluasi, Fantasi, Gambar, Analisis, dan Blur (Alifi, 2017, hal. 12-15).

e. Metode Scramble

Metode scramble menurut Taylor merupakan metode dalam sebuah pembelajaran yang dapat meningkatkan konsentrasi dan kecepatan berpikir siswa, metode ini secara tidak langsung menggabungkan otak kiri dan otak kanan dengan menjawab soal dengan menerka jawaban yang tersedia dalam kondisi acak (Huda, 2014, hal. 303).

Sesuai dengan sifat jawabannya scramble terdiri atas 3 macam bentuk, diantaranya Scramble kata, yaitu sebuah permainan menyusun katakata atau huruf-huruf yang telah dikacaukan atau diacak letaknya sehinggamembentuk suatu kata tertentu yang bermakna. Scramble kalimat, yaitu sebuah permainan menyusun kalimat berdasarkan dari kata-kata yang telah diacak. Scramble wacana, yaitu sebuah permaianan menyusun wacana secara logis berdasarkan klimat-kalmiat yang susunannya telah diacak (Shoimin, 2014, hal. 166).

Adapun langkah-langkah yang terdapat dalam metode scramble pada pembelajaran bahasa Indonesia yaitu sebagai berikut.

1) Guru menyajikan materi yang sesuai dengan kompetensi.

2) Buatlah pertanyaan yang sesuai dengan materi pembelajaran.

3) Buatlah jawaban yang telah diacak susuan huruf atau kata.

4) Guru membagikan lembar kerja sesuai dengan materi pembelajaran (Andayani, 2015 , hal. 199).

f. Metode Teka-teki Silang

Hisyam, Munthe dan Aryani (2008, hal. 71) menyatakan teka-teki 
Wulida Nurul Fauziah, dkk. Penggunaan Metode Pembelajaran... Halaman $230-243$ Jurnal Belajar Bahasa, ISSN 2502-5864, E-ISSN 2503-0329

Volume 3, No. 2, September 2018

silang dapat digunakan sebagai metode pembelajaran yang baik dan menyenangkan tanpa menghilangkan atau meninggalkan esensi belajar yang sedang berlangsung. Selain itu, Silbermen mengemukakan bahwa penggunaan metode pembelajaran aktif dapat melibatkan peserta didik secara langsung antara peserta didik dan guru, salah satunya melalui metode teka-teki silang (Mursilah, 2017, hal. 41).

Dalam pengguanaan metode tekateki silang, Hisyam, Munthe dan Aryani (2008, hal. 71) mengemukakan langkah-langkah yang digunakan dalam metode teka-teki silang yaitu sebagai berikut.

1) Tulislah kata-kata kunci, terminology atau nama-nama yang berhubungan dengan materi yang telah diberikan.

2) Buatkah kisi-kisi yang tepat dengan kata yang telah dipilih (seperti dalam teka-teki silang) hitamkan bagian yang tidak diperlukan.

3) Buat pertanyaan-pertanyaan yang jawabannya adalah kata-kata yang telah dibuat atau dapat juga mengarah kepada kata-kata tersebut.

4) Bagikan lembar teka-teki silang kepada peserta didik. Bisa individu atau kelompok.

5) Batasi waktu mengerjakan.

6) Beri hadiah kepada kelompok atau individu yang mengerjakan paling cepat dan benar.

\section{METODE PENELITIAN}

Penelitian ini dilakukan di Nirandonwitya School tingkat Mathayom tahun pelajaran 2017-2018 yang beralamat di Mueang Bangpoo, Narathiwat, Thailand bagian selatan. Metode penelitian yang digunakan dalam penelitian ini berupa metode deskriptif kualitatif. Metode penelitian kualitatif merupakan metode penelitian yang berdasarkan fenomena, digunakan untuk meneliti pada objek yang alamiah dimana peneliti adalah instrumen kunci dan hasil penelitian kualitatif lebih menekankan makna dari pada generalisasi (Sugiyono, 2016, hal. 15). Penelitian kualitiatif merupakan penelitian yang bersifat deskriptif, dimana data yang diperoleh berupa kata-kata, gambar-gambar atau rekaman (Sugiarto, 2015, hal. 8).

Dalam penelitian ini penulis meneliti objek dalam keadaan natural atau alami (tidak dimanipulasi). Peneliti hadir sebagai pengamat sekaligus berpartisipasi terlibat aktif dengan sumber data yang akan diteliti yaitu dalam proses pembelajaran bahasa Indonesia siswa Mathayom Nirandonwitya School untuk menganalisis penggunaan metode dalam pembelajaran bahasa Indonesia bagi pembelajar asing yang dilakukan pada siswa Mathayom Nirandonwityan School tahun pelajaran 2017/2018 yang dilakukan pada beberapa kelas, yaitu kelas 4i/2 (VII SMP), kelas IM/M (VII SMP), $1 \mathrm{M} / 3$ (X SMA), dan kelas 2M/3 (XI SMA). Data yang telah didapatkan kemudian dianalisis kemudian dideskripsikan dengan uraian kata-kata. 
Wulida Nurul Fauziah, dkk. Penggunaan Metode Pembelajaran... Halaman $230-243$ Jurnal Belajar Bahasa, ISSN 2502-5864, E-ISSN 2503-0329

Volume 3, No. 2, September 2018

Adapun teknik pengumpulan data yang dilakukan oleh peneliti yaitu menggunakan teknik trianggulasi. Dalam teknik triangulasi peneliti menggunakan teknik yang berbeda-beda, yaitu menggabungkan dari berbagai teknik pengumpulan data yang terdiri dari teknik observasi partisipatif, teknik wawancara mendalam, dan teknik dokumentasi (Sugiyono, 2016, hal. 330).

\section{PEMBAHASAN}

Berdasarkan penelitian yang telah dilakukan selama kurang lebih 3 minggu di Nirandonwitya School tahun pelajaran 2017-2018, maka peneliti menemukan delapan metode yang digunakan dalam pembelajaran bahasa Indonesia bagi pembelajar asing. Kedelapan metode tersebut dianalisis berdasarkan kesesuaian penggunaannya dengan teori yang ada. Kedelapan metode tersebut di antaranya yaitu metode baca tirukan, membaca berantai, demonstrasi, ceramah, deskripsi gambar, menyanyikan lagu, scramble dan teka-teki silang.

Metode baca tirukan digunakan dalam 3 kelas yaitu kelas $1 \mathrm{M} / 3,1 \mathrm{M} / \mathrm{M}$ dan kelas $2 \mathrm{M} / 3$ dengan materi pembelajaran yang berkaitan dengan teks atau cerita. Metode baca tirukan digunakan guru untuk meningkatkan kemampuan siswa dalam keterampilan menyimak dan membaca. Berdasarkan kemampuan siswa yang masih minim dalam membaca maka metode baca tirukan dapat dikatakan sesuai untuk digunakan dalam pembelajaran bahasa Indonesia. Namun dalam penggunaan metode baca tirukan ditemukan kelebihan dan kekurangannya.
Kelebihan yang terdapat dalam penggunaan metode baca tirukan yaitu siswa dapat mengetahui cara membaca yang benar sesuai dengan ejaan yang terdapat dalam teks tersebut, siswa lebih mudah memahami materi yang disampaikan daripada siswa harus membaca sendiri dengan kemampuan membaca yang masih rendah, dapat melatih kemampuan menyimak siswa, mengefektifkan waktu yang tersedia karena siswa dibantu oleh guru dalam memahami pembelajaran dan siswa cenderung lebih aktif ketika menemukan kata yang tidak mengerti siswa secara langsung bertanya kepada guru. Adapun kelemahannya yaitu tidak semua siswa dapat menirukan apa yang diucapkan guru, dan cukup menguras energi guru karena metode tersebut guru membacakan teks yang harus diikuti siswa dan terkadang guru harus mengulang 2-3 kali jika terdapat kata yang sulit dilafalkan.

Metode membaca berantai merupakan metode yang populer setelah metode baca tirukan, metode membaca berantai sering digunakan dalam pembelajaran bahasa Indonesia di Nirandonwitya School, selama dalam kegiatan observasi metode membaca berantai sering digunakan di kelas $2 \mathrm{M} / 3$. Metode membaca berantai dalam penggunaannya seringkali digunakan setelah metode baca tirukan yakni penggunaannya diterapkan dalam penyampaian materi yang berkaitan dengan teks yang cenderung panjang atau cerita, hal tersebut bertujuan untuk memperkuat siswa dalam meningkatkan 
Wulida Nurul Fauziah, dkk. Penggunaan Metode Pembelajaran... Halaman $230-243$ Jurnal Belajar Bahasa, ISSN 2502-5864, E-ISSN 2503-0329

Volume 3, No. 2, September 2018

kemampuan menyimak dan membaca. Metode membaca berantai dapat dinilai efektif pengunaannya dalam pembelajaran bahasa Indonesia di Nirandonwitya School, meskipun demikian metode baca berantai tidak terlepas dari kelebihan dan kekurangan. Kelebihan yang terdapat dalam metodemembaca tirukan diantaranya dapat meningkatkan kemampuan membaca siswa, dapat meningkatkan daya menyimak siswa, dapat mengefesiensikan waktu yang tersedia untuk menyelesaikan membaca teks panjang, siswa lebih mudah menemukan perkataan yang tidak dipahami dibandingkan hanya menyimak teks yang dibacakan guru, memicu konsentrasi siswa karena guru secara acak meminta siswa untuk membaca teks tersebut dan melatih kepercayaan diri siswa.

Metode demonstrasi merupakan metode yang digunakan dalam pembelajaran bahasa Indonesia di Nirandonwitya School, metode demonstrasi digunakan dalam proses pembelajaran dengan tujuan untuk meningkatkan kemampuan siswa dalam keterampilan menyimak, membaca dan berbicara. Berdasarkan observasi yang dilakukan metode demonstrasi digunakan di kelas $1 \mathrm{M} / 3$ dengan beberapa materi yang berbeda yaitu materi menyapa orang lain dan materi membaca puisi, kesesuaian metode demonstrasi dapat dilihat berdasarkan langkah-langkah yang dilakukan guru dalam proses pembelajaran dengan mengacu kepada langkahlangkah menurut teori sehingga metode tersebut dapat dikatakan sesuai namun capaian hasil belajar siswa tidak sesuai dengan yang diharapkan karena rendahnya kepercayaan diri yang dimiliki siswa. Adapun kelebihan dari metode demonstrasi yaitu dapat meningkatkan daya menyimak dan berbicara siswa, kecil kemungkinan terdapat kesalahankesalahan, karena siswa sebelumnya mendapat gambaran yang jelas dari guru, menumbuhkan rasa percaya diri dan melatih mental siswa, dan dapat memotivasi siswa untuk membuat karya dengan baik atau menguasai materi dengan baik. Selain itu, kelemahan yang terdapat dalam metode demonstrasi diantaranya membutuhkan waktu yang lama dan metode demonstrasi tidak akan efektif jika diterapkan pada kelas yang memiliki jumlah siswa banyak, karena akan ada kemungkinan peserta didik yang tidak mengamati demonstrasi yang dilakukan oleh temannya.

Metode ceramah yang digunakan dalam pembelajaran bahasa Indonesia di Nirandonwitya School diterapkan dalam beberapa kelas diantaranya kelas $4 \mathrm{i} / 2$ dengan materi diftong, dan kelas $1 \mathrm{M} / 3$ dengan materi struktur bahasa SPOK. Metode ceramah digunakan untuk meningkatkan kemampuan siswa dalam keterampilan menyimak dan meningkatkan pemahaman secara kognitif. Langkah-langkah penggunaan metode ceramah yang dilakukan guru dalam pembelajaran secara umum mendekati langkah-langkah yang dikemukakan dalam teori sehingga metode tersebut dapat dikatakan sesuai dalam penggunaannya. Adapun kelebihan yang terdapat dalam penggunaan metode 
Wulida Nurul Fauziah, dkk. Penggunaan Metode Pembelajaran... Halaman $230-243$ Jurnal Belajar Bahasa, ISSN 2502-5864, E-ISSN 2503-0329

Volume 3, No. 2, September 2018

ceramah yaitu materi dapat tersampaikan lebih banyak, karena pembelajaran berpusat pada guru dan dapat membantu siswa memperoleh informasi yang akurat yang tidak mudah diperoleh sendiri oleh siswa. Selain itu,kelemahan yang terdapat dalam metode ceramah diantaranya siswa cenderung pasif selama proses pembelajaran karena selama proses pembelajaran siswa hanya menyimak, memungkinkan tidak semua siwa dapat menyimak dengan baik, memungkinkan muncul kondisi kejenuhan yang dirasakan siswa dan memungkinkan ketidakpahaman siswa terhadap materi yang disampaikan secara verbal karena perbedaan bahasa.

Metode deskripsi gambar merupakan metode yang terdapat dalam pembelajaran bahasa Indonesia di Nirandonwitya School di mana dalam metode tersebut guru menggunakan gambar sebagai stimulus yang diberikan kepada siswa untuk melatih dan meningkatakan kemampuan siswa dalam keterampilan menulis dan membaca. Berdasarkan pengamatan yang dilakukan, metode deskripsi gambar digunakan di kelas $4 \mathrm{i} / 2$ dengan materi diftong dan kelas $2 M / 3$ dengan materi lingkungan. Dalam penggunaannya langkah-langkah guru dalam proses pembelajaran mendekati langkah-langkah yang dikemukakan teori sehingga metode tersebut dapat dinyatakan efektif. Adapun kelebihan yang terdapat dalam penggunaan metode deskripsi gambar yaitu menstimulus imajinasi siswa untuk membuat sebuah kalimat berdasarkan gambar, melatih siswa untuk menu- angkan isi pemikiran terhadap sesuatu dalam bentuk tulisan dan melatih kemampuan berbahasa siswa berupa keterampilan menulis dan membaca. Selain itu, terdapat pula kelemahan yang terdapat dalam penggunaan metode deskripsi gambar diantaranya membutuhkan waktu yang banyak jika diterapkan pada siswa yang berjumlah banyak karena siswa diminta untuk membaca satu persatu hasil deskripsi gambar di samping itu bagi pembelajar asing menuangkan ide dalam tulisan bahasa Indonesia membutuhkan waktu yang cukup lama karena siswa belum terampil dalam menulis bahasa Indonesia.

Metode menyanyikan lagu merupakan salah satu metode yang digunakan di Nirandonwitya School, metode tersebut dapat dikatakan metode yang menyenangkan karena siswa dapat belajar dengan santai dan materi lebih mudah diingat siswa melalui lagu. Metode tersebut digunakan di kelas $1 \mathrm{M} / \mathrm{M}$ dengan materi puisi, dan kelas $4 \mathrm{i} / 2$ dengan materi diftong. Berdasarkan langkah-langkah penggunaan metode menyanyikan lagu yang diterapkan oleh guru di Nirandonwitya School hampir menyerupai langkah-langkah yang dikemukakan dalam teori sehingga metode tersebut cukup efektif digunakan dalam pembelajaran. Dalam penggunaan metode menyanyikan lagu tidak terlepas dari kelebihan dan kelemahan, kelebihan dalam metode tersebut yaitu melatih kemampuan menyimak siswa dalam menerima pembelajaran, melatih cara berbiacara siswa mengenai kosa kata 
Wulida Nurul Fauziah, dkk. Penggunaan Metode Pembelajaran... Halaman $230-243$ Jurnal Belajar Bahasa, ISSN 2502-5864, E-ISSN 2503-0329

Volume 3, No. 2, September 2018

bahasa Indonesia serta materi yang disampaikan lebih mudah dipahami dan diingat oleh siswa karena metode yang digunakan termasuk metode yang menyenangkan. Adapun kelemahan yang terdapatdalam metode tersebut adalah membutuhkan waktu yang cukup banyak dan kesabaran guru yang ekstra, karena guru harus secara perlahan mengajarkan nada sekaligus kosa kata kepada siswa, hal tersebut dilakukan secara berulangulang agar siswa dapat menirukan nada dan kosa kata yang dicontohkan oleh guru.

Metode scramble merupakan metode permainan acak huruf atau acak kata yang diterapkan dalam pembelajaran bahasa Indonesia di Nirandonwitya School sehingga metode tersebut terskesan menyenangkan karena pembelajaran dilakukan sambil bermain. Metode scramble merupakan metode dalam sebuah pembelajaran yang dapat meningkatkan konsentrasi dan kecepatan berpikir siswa, metode ini secara tidak langsung menggabungkan otak kiri dan otak kanan dengan menjawab soal dengan menerka jawaban yang tersedia dalam kondisi acak (Taylor dalam Huda, 2014: 303). Metode scramble digunakan dalam pembelajaran dengan tujuan untuk meningkatkan kemampuan menulis siswa dan meningkatkan pemahaman siswa mengenai pembendaharaan kosa kata bahasa Indonesia. Metode ini diterapkan di kelas 4i/2 dengan materi vokal berganding denagn menggunakan scramble kata, kelas $2 \mathrm{M} / 3$ materi struktur bahasa SPOK dengan menggunakan scramble kalimat. Dengan mengacu terhadap langkah-langkah penggunaan metode scramble (Andayani, 2015, hal. 199), langkah-langkah yang digunakan oleh guru dalam pembelajaran bahasa Indonesia di Nirandonwitya School hampir menyerupai yang dikemukakan dalam teori meskipun terdapat beberapa perbedaan karena menyesuaikan dengan karakteristik peserta didik. Adapun kelebihan yang terdapat dalam metode scramble yaitu melatih kemampuan siswa dalam berpikir kritis memecahkan masalah dengan menyusun kosa kata yang telah diacak dalam kartu selain itu dapat membuat suasana kelas dalam pembelajaran tidak jenuh, karena metode ini bersifat permainan dalam pembelajaran serta melatih siswa dalam kemampuan menulis. Kelemahan yang terdapat dalam metode scramble diantaranya memerlukan waktu yang cukup lama, karena kemampuan menulis siswa, kemudian suasana kelas menjadi tidak tenang karena siswa aktif mencari jawaban serta masih terdapat siswa yang mengalami kesalahan dalam penyusunan kata.

Metode teka-teki silang merupakan metode pembelajaran aktif berbasis permainan dan menuntut siswa untuk berpikir kritis, metode tersebut digunakan dalam pembelajaran bahasa Indonesia di Nirandonwitya School di kelas $4 \mathrm{i} / 2$ dengan materi pembelajaran vokal berganding. Langkah-langkah yang digunakan guru dalam pembelajaran secara umum mendekati langkah-langkah penggunaan metode yang dikemukakan oleh Hisyam, Munthe dan Aryani (2008, hal. 71). Meskipun terdapat beberapa 
Wulida Nurul Fauziah, dkk. Penggunaan Metode Pembelajaran... Halaman $230-243$ Jurnal Belajar Bahasa, ISSN 2502-5864, E-ISSN 2503-0329

Volume 3, No. 2, September 2018

perbedaan, metode ini cukup efektif digunakan dalam pembelajaran bahasa Indonesia. Metode teka-teki silang dalam penggunaannya terdapat kelebihan dan kelemahan, kelebihannya yaitu membuat siswa lebih aktif dalam berpikir untuk mencari tahu jawaban dari pertanyaan yang diberikan dalam bentuk teka-teki silang, embuat suana pembelajaran yang lebih menarik sehingga tidak membuat siswa jenuh, dapat melatih kemampuan berbahasa siswa dalamketerampilan menulis, memperkaya dan melatih siswa dalam pembendaharaan kosa kata bahasa Indonesia serta melatih konsentrasi siswa dalam mengisi kotak-kotak kosong secara mendatar dan menurun.

\section{SIMPULAN}

Berdasarkan hasil penelitian yang dilakukan mengenai penggunaan metode pembelajaran bahasa Indonesia tingkat Mathayom di Nirandonwitya School Thailand Selatan tahun pelajaran 2017/2018, maka dapat disimpulkan terdapat delapan metode yang digunakan di beberapa kelas yaitu kelas $4 \mathrm{i} / 2,1 \mathrm{M} / \mathrm{M}$, $1 M / 3$ dan 2M/3. Kedelapan metode tersebut di anataranya metode baca tirukan, baca berantai, demonstrasi, ceramah, deskripsi gambar, metode menyanyikan lagu, scramble, dan metode teka-teki silang.

Penggunaan metode pembelajaran bahasa Indonesia di Nirandonwitya School tahun pelajaran 2017/2018 sudah sesuai dengan metode pembelajaran bahasa Indonesia bagi penutur asing. Hal tersebut dapat dilihat berdasarkan langkah-langkah penggunaan metode yang dilakukan oleh guru dalam pembelajaran bahasa Indonesia di Nirandonwitya School terdapat banyak kesamaan dengan langkah-langkah penggunaan dari berbagai metode menurut teori.

Setiap metode memiliki kelebihan dan kelemahan ketika diaplikasikan dalam proses pembelajaran, begitu pun dengan kedelapan metode tersebut. Kelebihan dari metode metode baca tirukan, membaca berantai, demonstrasi, ceramah, deskripsi gambar, menyanyikan lagu, scramble dan teka-teki silang dalam pembelajaran bahasa Indonesia di Nirandonwitya School yaitu dapat meningkatkan keterampilan berbahasa. Kelemahanya didukung oleh kendala dalam alokasi waktu dan fasilitas yang tersedia, buku ajar yang digunakan dalam pembelajaran bahasa Indonesia masih terbatas, yaitu satu buku untuk dua tingkatan.

\section{DAFTAR RUJUKAN}

Alifi, A. (2017). Rockstar Teacher. Yogyakarta: PT Bentang Pustaka.

Andayani. (2015 ). Problema dan Aksioma dalam Metodologi Pembelajaran Bahasa Indonesia. Yogyakarta: Deepublish.

Darmadi. (2017) ). Pengembangan model dan Metode Pembelajarandalam Dinamika Belajar Siswa. Yogyakarta: Deepublish.

Faturrohman, P., \& Sutikno. (2010). Strategi Belajar Mengajar. Bandung: PT Refika Aditama. 
Wulida Nurul Fauziah, dkk. Penggunaan Metode Pembelajaran... Halaman $230-243$ Jurnal Belajar Bahasa, ISSN 2502-5864, E-ISSN 2503-0329

Volume 3, No. 2, September 2018

Hasyim, Z., Munthe, B., \& Aryani, S. A. (2008). Strategi Pembelajaran Aktif. Yogyakarta: Insan Madani.

Huda, M. (2014). Model-model Pengajaran dan Pembelajaran. Yogyakarta: Pustaka Pelajar.

Roestiyah. (2001). Strategi Belajar Mengajar. Jakarta: Bina Aksara.

Said, \& Rahayu. (2017). Revolusi Mengajar Berbasis Neurosains. Jakarta: PRENADA.

Iskandarwassid. (2008). Strategi Saifuddin. (2014). Pengelolaan Pembelajaran Bahasa. Bandung: PT Remaja Rosda Karya Offset.

Kusmiatun, A. (2016). Mengenal BIPA dan Pembelajarannya. Yogyakarta: KMedia.

Maulana, d. (2015). Ragam Model Pembelajaran di Sekolah Dasar. Sumedang: UPI Sumendang Press.

Muliastuti, L. (2017). Bahasa Indoensia Bagi Penutur Asing. Jakarta: Yayasan Pustaka Obor Indonesia.

Mursilah. (2017). Penerapan Metode Pembelajaran Crossword Puzzle dalam Meningkatkan Hasil Belajar IPS Kelas XII SMK Nurul Huda Sukaraja. Jurnal IImiah Pendidikan dan Ekonomi , 1 , 3747.

Ngelu, M. (2015). Eksistensi Bahasa Indonesia di Mata Dunia pada Era MEA. Seminar Nasional Pendidikan Bahasa Indonesia. ISSN 2477-636X. Pembelajaran Teoretis dan Praktis. Yogyakarta: Deepublish.

Shoimin, A. (2014). 68 Model Pembelajaran Inovatif dalam Kurikulum 2013. Yogyakarta: Ar-Ruzz Media.

Sugiarto, E. (2015). Menyusun Proposal Penelitian Kualitatif Skripsi dan Tesis. Jakarta: Suaka Media.

Sugiyono. (2016). Metode Penelitian Pendidikan. Bandung: Alfabeta.

Sumiati, \& Asra. (2009). Metode Pembelajaran. Bandung: CV. Wacana Prima.

Tarigan, H. (2009). Metodologi Pengajaran Bahasa 1. Bandung: Angkasa.

Yamin, M. (2013). Strategi dan Metode dalam Model Pembelajaran. Jakarta: GP Press Group. 